\title{
PERBEDAAN EFEKTIVITAS PENGGUNAAN OBAT AMLODIPIN TUNGGAL DENGAN KOMBINASI AMLODIPIN DAN LISINOPRIL PADA PASIEN HIPERTENSI RAWAT INAP DI RS ' $X$ ' TABANAN TAHUN 2017
}

\author{
(DIFFERENCES IN THE EFFECTIVENESS OF THE USE OF DRUGS AMLODIPIN SINGLE \\ WITH A COMBINATION OF AMLODIPIN AND LISINOPRIL IN HYPERTENSIVE PATIENTS \\ HOSPITALIZED IN ' $X$ ' HOSPITAL 2017)
}

\section{NI NYOMAN WAHYU UDAYANI*•, NI WAYAN RIASTINI*, I MADE AGUS SUNADI PUTRA*}

\author{
*Akademi Farmasi Saraswati Denpasar, Jalan Kamboja No.11A, Denpasar, Bali
}

\begin{abstract}
Abstrak: Hipertensi merupakan gangguan kesehatan yang sering dijumpai dan termasuk masalah kesehatan penting karena angka prevalensi yang tinggi sehingga evaluasi penggunaan obatnya perlu dilakukan (WHO, 2011). Penelitian ini bertujuan untuk mengetahui perbedaan efektivitas penggunaan obat antihipertensi oral tunggal amlodipin dengan terapi kombinasi amlodipin dan lisinopril untuk pasien hipertensi rawat inap di RS ' $\mathrm{X}$ ' Tabanan pada tahun 2017. Penelitian ini merupakan jenis penelitian non-eksperimental dengan pengambilan data dilakukan secara retrospektif dengan menggunakan data rekam medis pasien yang diambil pada unit catatan rekam medis di ' $X$ ' Tabanan Hospital bulan Januari-Desember 2017. Penelitian dilakukan terhadap 36 subjek penelitian dengan terapi amlodipin tunggal dan 36 subjek penelitian dengan terapi kombinasi amlodipin dengan lisinopril. Hasilnya menunjukkan bahwa terdapat perbedaan efektivitas tekanan darah pasien hipertensi yang mendapat terapi amlodipin tunggal dan terapi amlodipin kombinasi dengan lisinopril untuk pasien hipertensi rawat inap di RS ' $X$ ' Tabanan pada tahun 2017 dengan nilai $p=0.042$ dan 0.038 .
\end{abstract}

Kata kunci: antihipertensi oral kombinasi, antihipertensi oral tunggal, hipertensi rawat inap.

Abstract: Hypertension is a health disorder that is often encountered and includes important health problems because of high prevalence rates so that evaluation of the use of the drug needs to be done (WHO, 2011). This study aims to determine the difference in the effectiveness of the use of single oral amlodipine antihypertensive drugs with combination therapy of amlodipine and lisinopril for inpatient hypertensive patients at ' $X$ ' Hospital in 2017. This research is a type of non-experimental research with data retrieval done retrospectively using patient medical record data taken on medical record unit at ' $X$ ' Tabanan Hospital in January-December 2017. The study was conducted on 36 study subjects with single amlodipine therapy and 36 study subjects with amlodipine combination therapy with lisinopril. The results show that there is a difference in blood pressure effectiveness of hypertensive patients receiving single amlodipine therapy and combination amlodipine therapy with lisinopril for inpatient hypertensive patients at ' $X$ ' Tabanan Hospital in 2017 with $p=0.042$ dan 0.038 .

Keywords: combination oral antihypertensive, hypertension of hospitalization, single oral antihypertensive.

\section{PENDAHULUAN}

Hipertensi atau tekanan darah tinggi adalah suatu peningkatan abnormal tekanan darah dalam pembuluh darah arteri secara terus menerus lebih dari suatu periode. Menurut World Health Organizations (WHO) batasan normal tekanan darah adalah 120/80 $\mathrm{mmHg}$, sedangkan seseorang dinyatakan mengidap hipertensi bila tekanan darahnya $>140 / 90 \mathrm{mmHg}$. Tekanan darah diantara normotensi dan hipertensi disebut Borderline Hypertension (Garis Batas Hipertensi). Batasan WHO tersebut tidak membedakan usia dan jenis kelamin (WHO, 2013).

Menurut Joint National Committee (JNC) VIII, rekomendasi target tekanan darah yang harus dicapai untuk usia di bawah 60 tahun adalah <140/90 $\mathrm{mmHg}$ dan target tekanan darah untuk usia di atas 60 tahun adalah $<150 / 90 \mathrm{mmHg}$, serta untuk semua usia dengan CKD dengan/tanpa DM adalah < 140/90 mmHg. Pada kebanyakan kasus, hipertensi terdeteksi saat pemeriksaan fisik karena alasan penyakit tertentu, sehingga sering disebut sebagai "silent killer". Tanpa disadari penderita mengalami komplikasi pada organ-organ vital seperti jantung, otak ataupun ginjal. Dimana gejala dapat bervariasi pada masing-masing individu dan hampir sama dengan gejala penyakit lainnya. Gejala-gejala akibat hipertensi, seperti pusing, gangguan penglihatan, dan sakit kepala, seringkali terjadi pada saat hipertensi sudah lanjut di saat tekanan darah sudah mencapai angka tertentu yang bermakna (Depkes, 2006).

Data dari WHO (World Health Organization) pada tahun 2013 menunjukkan bahwa terdapat 9,4 juta orang dari 1 milyar penduduk di dunia yang

• Author correspondence. e-mail: udayani.wahyu@yahoo.com 
meninggal akibat gangguan sistem kardiovaskular. Prevalensi hipertensi di Negara maju sebesar 35\% dan di Negara berkembang sebesar $40 \%$ dari populasi dewasa. Pada tahun 2025 diperkirakan kasus hipertensi terutama di Negara berkembang akan mengalami peningkatan $80 \%$ dari 639 juta kasus di tahun 2000, yaitu menjadi 1,15 milyar kasus. Prediksi ini didasarkan pada angka penderita hipertensi dan bertambahnya penduduk saat ini. Menurut hasil Riset Kesehatan Dasar (Riskesdas) tahun 2013 menunjukkan prevalensi hipertensi di Indonesia pada pasien dengan umur 18 tahun keatas sebesar 25,8\%.

Rumah Sakit ' $\mathrm{X}$ ' merupakan salah satu rumah sakit di kabupaten tabanan dengan jumlah pasien hipertensi yang cukup banyak dan penyakit ini memiliki kedudukan tertinggi dari 10 besar penyakit yang ada dan penderitanya selalu bertambah tiap tahunnya. Pada pengobatan hipertensi di $\mathrm{RS}$ ' $\mathrm{X}$ ' di Tabanan dapat dilakukan terapi pemberian obat intravena dan oral. Pemberian obat antihipertensi oral, seperti terapi tunggal golongan calcium channel blockers yaitu amlodipin dan terapi kombinasi golongan calcium channel blockers dengan golongan ACE-Inhibitor yaitu amlodipin dengan lisinopril.

Perbedaan terapi yang diberikan pada pasien sering kali berbeda, tergantung pada kondisi pasien. Efektivitas dari perbedaan keberhasilan kedua terapi tersebut belum diketahui dengan jelas. Berdasarkan uraian tersebut perlu dilakukan penelitian tentang perbedaan efektivitas penggunaan obat antihipertensi oral tunggal amlodipin dengan kombinasi antara amlodipin dengan lisinopril pada pasien hipertensi yang dirawat inap di ' $\mathrm{X}$ Tabanan.

\section{METODE PENELITIAN}

Rancangan Penelitian. Penelitian ini merupakan jenis penelitian non-eksperimental (observasional) analitik deskriptif dengan pendekatan cross sectional. Pengambilan data dilakukan secara retrospektif yaitu dengan menggunakan data rekam medis pasien yang diambil pada unit catatan rekam medis di $R S$ ' $\mathrm{X}$ ' Tabanan.

Subjek Penelitian. Populasi dari penelitian ini adalah semua pasien yang berusia 17 tahun keatas yang rawat inap di $R S$ ' $X$ ' di Tabanan pada tahun 2017 dengan diagnosa hipertensi yang mendapat terapi obat amlodipin tunggal dan kombinasi amlodipin dengan lisinopril. Sampel yang diambil dari populasi yang memenuhi kriteria penelitian.

\section{Kriteria Inklusi}

Pasien dengan diagnosis hipertensi yang berusia 17 tahun keatas yang dirawat inap di $R S$ ' $X$ ' di Tabanan Tahun 2017 yang mendapat terapi amlodipin tunggal dan kombinasi amlodipin dengan lisinopril.

2. Kriteria Eksklusi

a. Pasien hipertensi yang meninggal selama pengobatan.

b. Pasien hipertensi yang dirujuk ke rumah sakit lain.

Teknik Sampling. Teknik pengambilan sampel dalam penelitian ini menggunakan metode non probability sampling dengan teknik purposive sampling dimana pemilihan sampel dilakukan atas pertimbangan tertentu oleh peneliti (Saryono, 2011). Penelitian ini mengambil 72 sampel yang terdiri dari 36 sampel dengan terapi tunggal dan 36 sampel dengan kombinasi.

Teknik Pengumpulan Data. Dilakukan pengambilan data dari setiap pasien, data yang diambil diantaranya nama, nomor rekam medis, jenis kelamin, umur, lama rawat inap, diagnosis, hasil tekanan darah sistolik dan diastolik, obat yang diberikan selama perawatan dan dosis terapi yang diberikan selama perawatan. Selanjutnya dilakukan pemantauan penurunan tekanan darah pasien secara berkala selama rawat inap di X Tabanan.

Analisis Data. Data yang diperoleh selama penelitian terhadap pasien akan disajikan dalam bentuk tabel, sehingga didapatkan perbedaan efektivitas penggunaan antihipertensi amlodipin tunggal dengan kombinasi amlodipin dan lisinopril pada pasien hipertensi rawat inap di RS X Tananan dengan cara membandingkan rata-rata penurunan tekanan darah pasien dan dianalisis dengan uji statistik dengan taraf kepercayaan $95 \%$.

\section{HASIL DAN PEMBAHASAN}

Tabel 1. Karakteristik Subjek Penelitian Berdasarkan Jenis Kelamin

\begin{tabular}{|c|c|c|c|c|c|c|c|}
\hline \multirow{3}{*}{ No } & \multirow{3}{*}{$\begin{array}{c}\text { Jenis } \\
\text { Kelamin }\end{array}$} & \multicolumn{4}{|c|}{ Terapi } & \multirow{3}{*}{$\begin{array}{c}\text { Jumlah } \\
\text { Total }\end{array}$} & \multirow{3}{*}{$\begin{array}{l}\text { Persentase } \\
\text { (\%) Total }\end{array}$} \\
\hline & & \multicolumn{2}{|c|}{ Tunggal } & \multicolumn{2}{|c|}{ Kombinasi } & & \\
\hline & & Jumlah & Persentase (\%) & Jumlah & Persentase (\%) & & \\
\hline 1 & Laki-laki & 15 & 41,67 & 18 & 50 & 33 & 45,83 \\
\hline \multirow[t]{2}{*}{2} & Perempuan & 21 & 58,33 & 18 & 50 & 39 & 54,17 \\
\hline & TOTAL & 36 & 100,00 & 36 & 100 & 72 & 100,00 \\
\hline
\end{tabular}


Hasil penelitian terkait jenis kelamin menunjukkan sebagian besar pasien hipertensi adalah perempuan, yaitu sebesar $54,17 \%$. Jumlah sampel perempuan yang lebih besar dari laki-laki pada penelitian ini, tidak sesuai dengan literatur yang ada, dimana studi menunjukkan bahwa risiko hipertensi lebih rendah pada perempuan dibandingkan laki-laki. Akan tetapi pada masa premenopause perempuan cenderung memiliki tekanan darah yang lebih tinggi dibandingkan laki-laki. Hal ini karena adanya estrogen dalam tubuh perempuan, yang menjadi faktor pelindung dari penyakit kardiovaskuler. Dengan bertambahnya usia, hormon estrogen akan mengalami penurunan terutama setelah mengalami menopause. Peranan hormon estrogen sebagai antioksidan adalah untuk mencegah terjadinya oksidasi LDL (Low Density Lipoprotein). Selain itu, estrogen juga berperan dalam memperlebar pembuluh darah jantung sehingga aliran darah menjadi lancar dan suplai oksigen jantung tercukupi. Namun tidak menutup kemungkinan laki-laki juga memiliki resiko tinggi terkena hipertensi apabila pola hidup yang tidak sehat, karena jenis kelamin sebenarnya bukan salah satu faktor risiko hipertensi (Kusumastuty, I. dkk., 2016).

Tabel 2. Karakteristik Subjek Penelitian Berdasarkan Usia

\begin{tabular}{|c|c|c|c|c|c|c|c|}
\hline \multirow{3}{*}{ No } & \multirow{3}{*}{ Usia (Th) } & \multicolumn{4}{|c|}{ Terapi } & \multirow{3}{*}{$\begin{array}{c}\text { Jumlah } \\
\text { Total }\end{array}$} & \multirow{3}{*}{$\begin{array}{l}\text { Persentase } \\
\text { (\%) Total }\end{array}$} \\
\hline & & \multicolumn{2}{|c|}{ Tunggal } & \multicolumn{2}{|r|}{ Kombinasi } & & \\
\hline & & Jumlah & Persentase (\%) & Jumlah & Persentase (\%) & & \\
\hline 1 & $17-25$ & 0 & 0 & 1 & 2,78 & 1 & 1,39 \\
\hline 2 & $26-35$ & $\overline{0}$ & 0 & 1 & 2,78 & 1 & 1,39 \\
\hline 3 & $36-45$ & 2 & 5,56 & 1 & 2,78 & 3 & 4,17 \\
\hline 4 & $46-55$ & 9 & 25 & 10 & 27,78 & 19 & 26,39 \\
\hline 5 & $56-65$ & 11 & 30,56 & 13 & 36,10 & 24 & 33,33 \\
\hline 6 & $>65$ & 14 & 38,88 & 10 & 27,78 & 24 & 33,33 \\
\hline & OTAL & 36 & 100,00 & 36 & 100,00 & 72 & 100,00 \\
\hline
\end{tabular}

Hasil penelitian terkait usia, pasien paling banyak mengalami hipertensi adalah pasien dengan umur antara 56-65 tahun dan >65 tahun sebesar 33,33\%. Menurut Depkes (2006) pada kelompok umur $>55$ tahun lebih beresiko terkena komplikasi hipertensi. Beberapa penelitian yang dilakukan, ternyata terbukti bahwa semakin tinggi usia seseorang maka semakin tinggi tekanan darahnya. Hal ini disebabkan elastisitas dinding pembuluh darah semakin menurun dengan bertambahnya usia. Sehingga pembuluh darah menjadi lebih sempit dan dinding pembuluh darah menjadi kaku (Wijayanto, W. dan Satyabakti, 2014).

Tabel 3. Karakteristik Subjek Penelitian Berdasarkan Diagnosa Penyakit

\begin{tabular}{cccccccc}
\hline \multirow{2}{*}{ No } & \multirow{2}{*}{ Diagnosa } & \multicolumn{4}{c}{ Terapi } & Jumlah & Persentase \\
\cline { 3 - 6 } & & \multicolumn{3}{c}{ Tunggal } & Kombinasi & Jotal & (\%) Total \\
\hline $\mathbf{1}$ & $\begin{array}{l}\text { Hipertensi tanpa } \\
\text { komplikasi }\end{array}$ & 5 & 13,89 & 7 & 19,44 & 12 & 16,67 \\
\hline $\begin{array}{l}\text { Hipertensi } \\
\text { dengan } \\
\text { komplikasi }\end{array}$ & 31 & 86,11 & 29 & 80,56 & 60 & 83,33 \\
\hline & TOTAL & 36 & 100,00 & 36 & 100,00 & 72 & 100,00 \\
\hline
\end{tabular}

Hasil penelitian terkait diagnosa penyakit terlihat bahwa pasien hipertensi tanpa komplikasi $16,67 \%$ dan dengan komplikasi sebesar 83,33\%. Karena pada kebanyakan kasus, hipertensi terdeteksi saat pemeriksaan fisik karena alasan tertentu. Pasien yang mengidap hipertensi secara umum terlihat sehat, sehingga tidak menyadari bahwa dirinya telah menderita penyakit tekanan darah tinggi. Tekanan darah tinggi dalam jangka waktu lama akan merusak endothel arteri dan mempercepat atherosklerosis, serta dapat menimbulkan komplikasi berupa kerusakan organ pada jantung, otak, ginjal, mata dan pembuluh darah perifer. Pengendalian berbagai faktor risiko pada hipertensi sangat penting untuk mencegah komplikasi kardiovaskular. Faktor risiko yang dapat dimodifikasi, antara lain: tekanan darah, kelainan metabolik (Diabetes Mellitus, lipid darah, asam urat dan obesitas), merokok, alkohol dan inaktivitas, sedangkan yang tidak dapat dimodifikasi, antara lain: usia, jenis kelamin dan faktor genetik (Gunawan, S.G. dkk., 2007). 
Tabel 4. Karakteristik Subjek Penelitian Berdasarkan Terapi Pengobatan

\begin{tabular}{clcc}
\hline No & \multicolumn{1}{c}{ Terapi } & Jumlah & Persentase (\%) \\
\hline $\mathbf{1}$ & Terapi Tunggal Amlodipin & 36 & 50,00 \\
\hline $\mathbf{2}$ & Terapi Kombinasi Amlodipin+Lisinopril & 36 & 50,00 \\
\hline & TOTAL & $\mathbf{7 2}$ & $\mathbf{1 0 0}$ \\
\hline
\end{tabular}

Terapi pengobatan antihipertensi tidak hanya terdiri dari antihipertensi tunggal tetapi ada juga yang menggunakan kombinasi dua antihipertensi. Hasil penelitian menunjukkan algoritma pengobatan hipertensi pada tahap awal pengobatan hipertensi stage I lebih banyak dengan terapi tunggal. Hal ini disebabkan hipertensi stage I masih dapat diturunkan dengan satu macam obat antihipertensi (Tandililing, S. dkk., 2017). Sedangkan, terapi kombinasi diberikan bagi pasien hipertensi yang disertai dengan komplikasi penyakit kardiovaskular lainnya, seperti: diabetes mellitus dan gagal jantung. Pemberian dua macam obat sebagai terapi juga disarankan bila didapatkan tekanan darah lebih dari $20 / 10 \mathrm{mmHg}$ diatas target tekanan darah yang ditentukan (Depkes, 2006). Pada penggunaan antihipertensi secara tunggal, amlodipin merupakan golongan Calcium
Channel Blocker (CCB) yang banyak diberikan karena obat ini sangat bermanfaat mengatasi hipertensi yang bekerja dengan cara menghambat ion kalsium masuk ke dalam vaskularisasi otot polos dan otot jantung sehingga mampu menurunkan tekanan darah. Amlodipin sering dikombinasikan dengan senyawa antihipertensi lainnya, seperti golongan Angiotensin Converting Enzyme Inhibitors (ACEI), yaitu lisinopril. Terapi dengan pengobatan kombinasi pada pasien hipertensi dianjurkan, karena: mempunyai efek aditif, mempunyai efek sinergisme, mempunyai sifat saling mengisi, penurunan efek samping masing-masing obat, mempunyai cara kerja yang saling mengisi pada organ target tertentu, serta adanya "fixed dose combination" akan meningkatkan kepatuhan pasien (Depkes, 2006).

Tabel 5. Karakteristik Subjek Penelitian Berdasarkan Komplikasi

\begin{tabular}{|c|c|c|c|c|c|c|c|}
\hline \multirow{3}{*}{ No } & \multirow{3}{*}{ Komplikasi } & \multicolumn{4}{|c|}{ Terapi } & \multirow{3}{*}{$\begin{array}{c}\text { Jumlah } \\
\text { Total }\end{array}$} & \multirow{3}{*}{$\begin{array}{l}\text { Persentase } \\
\text { (\%) Total }\end{array}$} \\
\hline & & \multicolumn{2}{|c|}{ Tunggal } & \multicolumn{2}{|c|}{ Kombinasi } & & \\
\hline & & Jumlah & Persentase (\%) & Jumlah & Persentase (\%) & & \\
\hline 1 & HT+Stroke & 13 & 92,86 & 8 & 100 & 21 & 95,45 \\
\hline 2 & $\mathrm{HT}+\mathrm{CKD}$ & 1 & 7,14 & 0 & 0 & 1 & 4,55 \\
\hline & TOTAL & 14 & 100,00 & 8 & 100,00 & 22 & 100,00 \\
\hline
\end{tabular}

Hasil penelitian terkait komplikasi terlihat bahwa penyakit komplikasi stroke paling banyak ditemukan, yaitu sebesar $95,45 \%$. Hal ini terjadi karena supply darah ke otak yang disebabkan oleh gumpalan atau sumbatan pada pembuluh darah yang akan menyebabkan berkurangnya pasokan oksigen dan nutrisi ke otak sehingga terjadi kerusakan pada jaringan otak. Tingginya angka kejadian stroke pada penelitian ini, kemungkinan juga disebabkan oleh banyaknya pasien stroke yang memiliki riwayat hipertensi yang tidak terkontrol. Hal ini dipicu juga oleh faktor stres dan aktifitas fisik yang cukup berat yang mengakibatkan lonjakan tekanan darah yang drastis sehingga terjadi stroke. Gejala stroke adalah: kelemahan mendadak atau hilangnya rasa dari muka, tangan dan kaki, biasanya satu sisi dari tubuh, serta bicara tidak jelas atau sama sekali tidak bisa bicara. Komplikasi lain yang terjadi, yaitu Chronic Kidney Disease (CKD) sebanyak 4,55\%. Hipertensi merupakan salah satu faktor inisiasi yang mengawali kerusakan ginjal dan juga sebagai faktor progesif yang dapat mempercepat penurunan fungsi ginjal. Hal ini karena volume darah yang mengalir melalui ginjal berkurang dan tekanan darah di glomerulus ginjal menurun karena penyempitan arteri setempat (Tjay, T.H. dan Rahardja, K., 2007).

Tabel 6. Karakteristik Subjek Penelitian Berdasarkan Tekanan Darah

\begin{tabular}{|c|c|c|c|c|c|c|c|c|}
\hline \multirow{3}{*}{ No } & \multirow{3}{*}{$\begin{array}{c}\text { Klasifikasi } \\
\text { Tekanan } \\
\text { Darah }\end{array}$} & \multirow{3}{*}{$\underset{(\mathbf{m m H g})}{\text { TDS }}$} & \multicolumn{4}{|c|}{ Terapi } & \multirow{3}{*}{$\begin{array}{c}\text { Jumlah } \\
\text { Total }\end{array}$} & \multirow{3}{*}{$\begin{array}{l}\text { Persentase } \\
\text { (\%) Total }\end{array}$} \\
\hline & & & \multicolumn{2}{|r|}{ Tunggal } & \multicolumn{2}{|c|}{ Kombinasi } & & \\
\hline & & & Jumlah & Persentase (\%) & Jumlah & Persentase (\%) & & \\
\hline 1 & $\mathrm{HT}+$ Stroke & 140-159 & 13 & 92,86 & 8 & 100 & 21 & 95,45 \\
\hline 2 & $\mathrm{HT}+\mathrm{CKD}$ & $\geq 160$ & 1 & 7,14 & 0 & 0 & 1 & 4,55 \\
\hline & \multicolumn{2}{|c|}{ TOTAL } & 14 & 100,00 & 8 & 100,00 & 22 & 100,00 \\
\hline
\end{tabular}

Pada penelitian ini, penggunaan obat pada pasien hipertensi cukup banyak. Penggunaan obat yang banyak ini sangat beresiko menimbulkan interaksi antara satu obat dengan obat lain sekalipun semua pemberian obat terindikasi secara klinis. Pada penelitian ini, sebagian besar pasien berusia lanjut, 
dimana pada masa ini terjadi penurunan fungsi ginjal dan hepar yang menyebabkan perubahan proses farmakodinamik dan farmakokinetik dari obat yang digunakan sehingga lebih beresiko mengalami interaksi yang merugikan. Dengan banyaknya jumlah obat, efek samping yang mungkin terjadi juga akan lebih banyak. Dengan timbulnya efek yang tidak diinginkan ini kadangkala membutuhkan terapi/obat tambahan untuk mengatasi masalah tersebut.

Tabel 7. Uji Normalitas dengan One-Sample Kolmogorov-Smirnov One-Sample Kolmogorov-Smirnov Test

\begin{tabular}{cccc}
\hline & \multicolumn{3}{c}{ One-Sample Kolmogorov-Smirnov Test } \\
& & $\begin{array}{c}\text { Tekanan darah sistolik pasien } \\
\text { hipertensi }\end{array}$ & $\begin{array}{c}\text { Tekanan darah diastolik pasien } \\
\text { hipertensi }\end{array}$ \\
\hline \multirow{2}{*}{ Normal Parametersa } & & 72 & 72 \\
\cline { 2 - 4 } & Mean & -8.9826 & -5.3186 \\
\cline { 2 - 4 } Most Extreme Differences & Std. Deviation & 4.06689 & 2.42536 \\
\cline { 2 - 4 } & Absolute & .142 & .121 \\
\cline { 2 - 4 } & Positive & .069 & .121 \\
\cline { 2 - 4 } & Negative & -.142 & 1.096 \\
\hline Kolmogorov-Smirnov Z & 1.207 & .240 \\
\hline Asymp. Sig. (2-tailed) & .108 & \\
\hline
\end{tabular}

a. Test distribution is Normal.

Independent Samples Test Independent Samples Test

Levene's Test for Equality of Variances t-test for Equality of Means

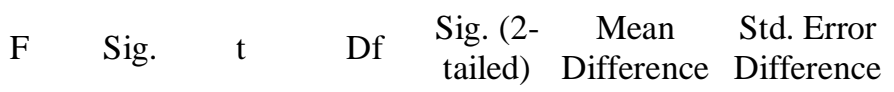

95\% Confidence Interval of the

\begin{tabular}{|c|c|c|c|c|c|c|c|c|c|c|}
\hline & & & & & & & & & Lower & Upper \\
\hline \multirow{2}{*}{$\begin{array}{c}\text { Tekanan darah } \\
\text { sistolik pasien } \\
\text { hipertensi }\end{array}$} & $\begin{array}{c}\text { Equal variances } \\
\text { assumed }\end{array}$ & 1.743 & .191 & 2.076 & 70 & .042 & 1.94528 & .93698 & .07653 & 3.81403 \\
\hline & $\begin{array}{c}\text { Equal variances } \\
\text { not assumed }\end{array}$ & & & 2.076 & 68.676 & .042 & 1.94528 & .93698 & .07589 & 3.81466 \\
\hline \multirow{2}{*}{$\begin{array}{c}\text { Tekanan darah } \\
\text { diastolik pasien } \\
\text { hipertensi }\end{array}$} & $\begin{array}{c}\text { Equal variances } \\
\text { assumed }\end{array}$ & 1.490 & .226 & 2.114 & 70 & .038 & 1.18000 & .55819 & .06672 & 2.29328 \\
\hline & $\begin{array}{c}\text { Equal variances } \\
\text { not assumed }\end{array}$ & & & 2.114 & 67.305 & .038 & 1.18000 & .55819 & .06594 & 2.29406 \\
\hline
\end{tabular}
Difference

\begin{tabular}{llllll}
\hline \multicolumn{7}{c}{ Group Statistics } & & \\
\hline & $\begin{array}{l}\text { Terapi yang diberikan pada pasien } \\
\text { hipertensi }\end{array}$ & $\mathrm{N}$ & Mean & Std. Deviation & Std. Error Mean \\
\hline Amlodipin dosis tunggal & 36 & -8.0100 & 3.68904 & .61484 \\
\hline $\begin{array}{l}\text { Tekanan darah } \\
\text { sistolik pasien } \\
\text { hipertensi }\end{array}$ & Amlodipin + Lisinopril & 36 & -9.9553 & 4.24224 & .70704 \\
\hline $\begin{array}{l}\text { Tekanan darah } \\
\text { diastolik pasien } \\
\text { hipertensi }\end{array}$ & Amlodipin dosis tunggal & 36 & -4.7286 & 2.11802 & .35300 \\
\cline { 2 - 6 } & Amlodipin + Lisinopril & 36 & -5.9086 & 2.59437 & .43239 \\
\hline
\end{tabular}

Uji statistik dalam penelitian ini membandingkan kedua kelompok dengan menggunakan skala data numerik. Dari uji normalitas dengan One Sample KolmogorovSmirnov, diketahui bahwa nilai signifikansi (p) untuk data tekanan darah sistolik sebesar 0,108 (p > $0,05)$ dan tekanan darah diastolik sebesar 0,240 (p $>0,05)$, hal ini menunjukkan bahwa data tekanan darah sistolik dan diastolik terdistribusi normal. Karena data terdistribusi normal dilakukan uji statistik dengan uji $\mathrm{t}$ tidak berpasangan (Independent Samples T Test) dengan interval kepercayaan 95\%. Berdasarkan hasil uji
Independent Samples T Test dari data diatas, dapat diketahui terlebih dahulu dengan melakukan uji $\mathrm{F}$ (Levene's test) yang menunjukkan nilai signifikansi (p) untuk tekanan darah sistolik pasien hipertensi sebesar 0,191 ( $\mathrm{p}>0,05)$ dan nilai signifikansi (p) tekanan darah diastolik sebesar 0,226 ( $\mathrm{p}>0,05)$, hasil ini menunjukkan bahwa varian data tekanan darah sistolik dan diastolik pasien hipertensi adalah sama (equal variances assumed), selanjutnya dilakukan uji t pada baris equal variances assumed. Dari hasil uji Independent samples t-test tekanan darah sistolik pasien hipertensi diketahui nilai signifikansi (p) sebesar 0,042 (p < 0,05) dan 
tekanan darah diastolik pasien hipertensi dengan nilai signifikansi (p) sebesar 0,038 (p<0,05), sehingga dapat disimpulkan bahwa terdapat perbedaan efektivitas tekanan darah pasien hipertensi yang mendapat terapi amlodipin tunggal dan terapi amlodipin kombinasi dengan lisinopril. Dalam hal ini terapi amlodipin kombinasi lisinopril jauh lebih efektif dalam menurunkan tekanan darah pasien hipertensi ditunjukkan dari nilai rata-rata penurunan tekanan darah sistolik yang diberikan terapi amlodipin kombinasi dengan lisinopril sebesar -9,96 dan tekanan darah diastolik dengan terapi amlodipin kombinasi dengan lisinopril sebesar -5,91, dibandingkan dengan penurunan tekanan darah sistolik dengan obat amlodipin tunggal sebesar $-8,01$ dan tekanan darah diastolik obat amlodipin tunggal sebesar $-4,73$.

\section{SIMPULAN}

Dari hasil penelitian yang dilakukan dapat disimpulkan bahwa tekanan darah sistolik pasien hipertensi diketahui nilai signifikansi (p) sebesar $0,042(\mathrm{p}<0,05)$ dan tekanan darah diastolik pasien hipertensi dengan nilai signifikansi (p) sebesar $0,038$ ( $\mathrm{p}<0,05)$, sehingga dapat disimpulkan bahwa terdapat perbedaan efektivitas tekanan darah pasien hipertensi yang mendapat terapi amlodipin tunggal dan terapi amlodipin kombinasi dengan lisinopril untuk pasien hipertensi rawat inap di RS 'X'di Tabanan pada tahun 2017.

\section{UCAPAN TERIMA KASIH}

1. Ni Wayan Riastini yang membantu dalam pengambilan data.

2. Direktur RS ' $X$ ' di Tabanan yang memberikan ijin dalam pengambilan data.

3. LPPM Akademi Farmasi Saraswati Denpasar yang telah membantu jalannya penelitian.

\section{DAFTAR PUSTAKA}

American Society of Hypertension, 2015, "Clinical Practice Guidelines for the Management of Hypertension in the Community", America, ASH.

Dahlan, M.S. 2013, Besar Sampel Dan Cara Pengambilan Sampel Edisi 3, Salemba Medika, Jakarta. Indonesia.

Direktorat Bina Farmasi Komunitas dan Klinik Ditjen Bina Kefarmasian dan Alat Kesehatan. 2006, "Pharmaceutical Care untuk Penyakit Hipertensi”, Jakarta, Departemen Kesehatan RI.

Gunawan, S.G., Syarif, A., Estuningtyas, A., Setiawati, A., Arif, A., Bahry, B., dkk. 2007, Farmakologi dan Terapi Edisi 5, Departemen Farmakologi dan Terapeutik FKUI, Balai Penerbit FKUI, Jakarta, Indonesia.

JNC-7. 2003, The Seventh Report of the Joint National Committee on Prevention, Detection, Evaluation, and Treatment of High Blood Pressure.

JNC-8. 2014, The Eight Report of the Joint National Committee Hypertension Guidelines: An InDepth Guide.

Notoatmodjo, S. 2010, Metodelogi Penelitian Kesehatan, Rineka Cipta, Jakarta. Indonesia.

Saryono. 2011, Metodologi Penelitian Kesehatan, Mitra Cendikia Press, Jogjakarta. Indonesia.

Saryono. 2011, Metodologi Penelitian Kesehatan, Mitra Cendikia Press, Jogjakarta. Indonesia.

Tjay, T.H. dan Rahardja, K. 2007, Obat-Obat Penting: Khasiat, Penggunaan, dan Efek-Efek Sampingnya Edisi IV, PT. Elex Media Komputindo, Jakarta.

WHO.2013.www.who.int diakses pada tanggal 8 september 2014. 